\title{
Exploration on the Team Teaching Mode of Military Basic Curriculum Courses Based on Ability Generation
}

\author{
Bo Zhang*, Liang Zhang, Ying Zhang, Xiaonan Wu, Wenhui Hao
}

\author{
College of Information and Communication, National University of Defense Technology, China \\ *Corresponding author. Email:6059018@qq.com
}

\begin{abstract}
The contents of the military basic curriculum courses are closely related to students' life and death in combat. There is a strong demand for the application of military basic curriculum courses after the NCO cadets being trained. In accordance with the basic concepts of "combat first, demand traction, ability-based, and educating cadets for war", the paper establishes the thinking of reforming the team teaching of military basic curriculum courses based on "demand traction, ability-based, breaking boundaries, and system integration", which provides an effective and practical reference for military basic curriculum courses reform.
\end{abstract}

Keywords: Military basic curriculum courses, team teaching, ability generation

\section{INTRODUCTION}

The contents of military basic curriculum courses are closely related to students' life and death in combat. Compared with the academic education trainees, the noncommissioned vocational and technical education trainees have a relatively short education system, and there is a strong demand for the comprehensive application of military basic curriculum courses on their posts after the training. In accordance with the basic concepts of "combat first, demand traction, ability-based, and educating cadets for war", the paper systematically combed the relationship among the military basic curriculum courses which are related to the generation of combat abilities, based on a careful study of the military basic curriculum courses required for the generation of combat abilities for vocational and technical education cadets. The study establishes the thinking of reforming the teaching of military basic curriculum courses based on "demand traction, ability-based, breaking boundaries, and system integration". By giving a full play to the individual advantages of the teachers and the group's advantages, the synergy effect of team teaching is fully demonstrated, so that the military basic curriculum courses will not only retain the professionalism of the course, but also maintain the consistency and coherence of the subjects, as well as provide an effective practical reference for the reform of military basic curriculum courses.

\section{DEVELOP A TEACHING REFORM PLAN FOR MILITARY BASIC CURRICULUM COURSES ON THE BASIS OF ABILITY GENERATION AND DEMAND TRACTION}

\begin{abstract}
According to the results of the special investigations organized by us in the previous period, the military basic teaching implemented by the current academy can basically meet the needs of the formation of skills, but there is still a significant gap in the practical use of the knowledge and skills learned by students. The main reasons for this situation are as follows: First, the basic military courses are not closely related to each other, and there exists a gap between the basic courses and actual needs. Second, the training contents and the combat ability generation are not closely connected, with "more emphasis on skills training, less emphasis on practical application". Third, the structure of faculty's ability and quality is single, resulting some knowledge and skills are lack. Therefore, after careful research, the basic concepts of "combat first, demand traction, ability-based, and educating cadets for war" have been clarified and a teaching mode reform work plan has been worked out with goals to meet the combat needs of $\mathrm{NCO}$ trainees as well as to build a military comprehensive teaching mode reform based on students' combat ability generation.

The reform is divided into three stages: the first stage focuses on the study of the basic connotation of team teaching, combing and integrating the military basic curriculum courses group that meets the needs of the combat ability generation of NCO cadets; the second stage
\end{abstract}


is to complete the basic construction of the courses, optimize the teaching contents, and explore new teaching methods; the third stage is to complete the supporting construction of the courses and strengthen the application and promotion.

\section{CLARIFY THE CONCEPT AND REDEFINE THE BASIC CONCEPT OF "TEAM TEACHING"}

In the pre-research process of the project, we found that the two concepts of "teaching team" and "team teaching" are often mixed in the current theoretical research. Therefore, we focused on the redefinition of the concept of team teaching and the comparative study of the similarities and differences between the two concepts. Through our careful research, we believe that:

Team teaching is a new form of teaching organization. It refers to the use of a number of teaching forces to achieve a certain teaching goal and improve the ability of the trainees, based on the corresponding course groups which have logical connection in knowledge, methods, and skills. The connected course group is the basic platform. According to certain principles, a group of people are selected to form the team, and both the advantages of the individual team members and the group are fully utilized around the teaching task, with the implementation of large professional, pan curriculum teaching organization.

The ability generation of trainees is the focus of team teaching, and is also the basis for the implementation of large-scale professional and pan curriculum teaching; the construction of a reasonable and effective curriculum group is an important carrier for efficient implementation of team teaching; the establishment of a lean, collaborative and efficient teaching team with division of labor and cooperation to achieve a certain teaching goal and complementary knowledge and skills is the key to team teaching.

The similarities and differences between teaching team and team teaching are shown in Table 1.

\section{FOCUS ON COMBAT AND RESTRUCTURE THE MILITARY BASIC CURRICULUM COURSES GROUP BASED ON ABILITY GENERATION}

The organization and implementation of team teaching should always focus on the generation of the ability of the cadets. The construction of a reasonable and effective course group is an important carrier for the efficient implementation of team teaching. In accordance with the idea of "combining independent courses with embedded teaching contents", we should carefully sort out the basic military skills in the personnel training plan and military training and assessment outline that are helpful to improve the combat ability of the cadets, and effectively integrate the corresponding basic military courses based on combat needs, with logical connection in knowledge, methods, skills, etc. So that establish the military basic course group generated by the combat ability of the cadets.

Table 1 Comparison between Team Teaching and Teaching Team

\begin{tabular}{|c|c|c|c|c|c|}
\hline & \multirow[b]{2}{*}{ Similarities } & \multicolumn{4}{|c|}{ Differences } \\
\hline & & Personnel & $\begin{array}{c}\text { Quality } \\
\text { Requirements }\end{array}$ & Targets & Focus \\
\hline $\begin{array}{l}\text { Team } \\
\text { Teaching }\end{array}$ & $\begin{array}{l}\text { Team } \\
\text { teaching also } \\
\text { needs to form } \\
\text { a team to } \\
\text { implement } \\
\text { teaching. } \\
\text { Both } \\
\text { teaching } \\
\text { team and } \\
\text { team } \\
\text { teaching can }\end{array}$ & $\begin{array}{l}\text { selected from a } \\
\text { number of } \\
\text { teaching and } \\
\text { research offices, } \\
\text { departments, } \\
\text { institutions and } \\
\text { related } \\
\text { departments, and } \\
\text { even including } \\
\text { instructors } \\
\text { outside the } \\
\text { military } \\
\text { instructors }\end{array}$ & $\begin{array}{l}\text { knowledge and } \\
\text { skills of } \\
\text { personnel should } \\
\text { be } \\
\text { complementary }\end{array}$ & $\begin{array}{l}\text { to achieve } \\
\text { a certain } \\
\text { teaching } \\
\text { goal and to } \\
\text { improve a } \\
\text { certain } \\
\text { ability }\end{array}$ & $\begin{array}{l}\text { the generation } \\
\text { of trainees' } \\
\text { abilities }\end{array}$ \\
\hline $\begin{array}{l}\text { Teaching } \\
\text { Team }\end{array}$ & $\begin{array}{l}\text { promote and } \\
\text { improve the } \\
\text { quality of one } \\
\text { or more } \\
\text { courses. }\end{array}$ & $\begin{array}{l}\text { usually } \\
\text { composed of a } \\
\text { section or a } \\
\text { group of faculty } \\
\text { members for } \\
\text { certain course }\end{array}$ & $\begin{array}{l}\text { knowledge and } \\
\text { skills of } \\
\text { personnel should } \\
\text { be similar }\end{array}$ & $\begin{array}{l}\text { to improve } \\
\text { the quality } \\
\text { of teaching }\end{array}$ & $\begin{array}{l}\text { the } \\
\text { improvement } \\
\text { of the quality } \\
\text { of subject } \\
\text { construction or } \\
\text { course } \\
\text { construction }\end{array}$ \\
\hline
\end{tabular}


The teaching contents must focus on the core of "focusing on combat and educating cadets for war", putting emphasis on practicality, applicability and aiming at "8 sub-capacity requirements". It should take the generation of students' combat ability as the goal, carefully sorting out the teaching contents, clarifying the relationship between the courses corresponding to the military basic skills required by the generation of NCO cadets' combat ability, and carrying out interdisciplinary and comprehensive curriculum design by way of applying multi-faceted knowledge comprehensively within the combat process and combat requirements.

\section{SET UP A TEACHING TEAM TO MEET THE NEEDS OF ABILITY GENERATION}

It is the key to carry out team teaching to set up a lean, cooperative and efficient teaching team which can meet the practical needs of NCO cadets and achieve the teaching objectives through division of labor and cooperation and the complement of knowledge and skills. It is necessary to organize the teaching team of military basic curriculum courses in accordance with the idea of "combining the individual advantages of instructors with the group advantages of the team", which can effectively make up for the practical problems of a single faculty quality structure and the lack of knowledge and skills, and can fully demonstrate the synergistic effect of team teaching. First, clarify the principles of establishing teaching teams. The characteristics of short learning system, high requirements of post competency and heavy training tasks for NCO cadets require that the teaching team should be established under the guidance of meeting the combat needs, by following the principles of focusing on the combat needs and being supplemented by courses. It should consist of a collaborative faculty in military basic subjects required in combat. The form of centralized selection and voluntary participation is adopted in the establishment of the teaching team, that is to say, the individual should apply first, and then the relevant management department will review according to the needs of the team's teaching. Second, clarify the composition of the teaching team and the division of labor. Normally, the teaching team should include the leaders of the college and related departments (offices), teachers of relevant subjects and part-time instructors selected from the army. Among them, the teachers of relevant subjects and part-time instructors are the main body of the implementation of teaching, and they are the backbones of teaching selected to generate cadets' combat ability. The leaders of the college and related departments (offices) are the managers of the team as well as the coordinators to avoid and reduce the conflict between the original administrative system and the team. Such a composition and division of labor is not only conducive to achieving strong alliances and complementary advantages, but also conducive to teamwork and integration. Third, clarify the management responsibilities of the teaching team. The teaching team implements a system of division of responsibility on teaching tasks, with the completion of teaching tasks as the management bottom line. The administrative relationship of the team members is still subordinate to the original unit, and the daily management mainly focuses on teaching tasks, teaching contents and teaching organization and implementation. It is necessary to clarify responsibilities and division of labor, implement evaluation rewards and punishments, at the same time focus on coordinating team relationships, and vigorously strengthen team echelon construction. Taking combat needs as the traction, and on the basis of post requirements, organize military basic curriculum courses teaching teams, break the boundaries between courses, disciplines, and various teaching units, and give full play to the individual advantages of teachers to achieve their own strengths and teach for battle. Through collaboration, solidify it into a mechanism and form an integrated teaching force.

\section{EDUCATE CADETS FOR WAR, ORGANIZE AND IMPLEMENT CAREFULLY BASED ON THE DEMAND OF ABILITY GENERATION}

In the specific implementation of courses teaching, we should follow the idea of "focusing on the combination of skills formation and highlighting practical application", and closely adhere to the three ability generating modules, which are basic ability, core ability and expanding ability, to organize and design curriculum or special topic. Each ability module can be subdivided into several corresponding knowledge and skills. In the arrangement of teaching process, it is organized and implemented according to the three stages: basic ability teaching, core ability teaching, and expanding ability teaching. This is not only in line with the cognitive law, but also conducive to the shaping and improvement of the ability of training objects.

For example, in the past, the teaching of "shooting with small arms" was mainly conducted by shooting instructors. The focus was on developing the shooting skills of the trainees. However, there is a gap between having shooting skills and forming combat abilities, because on the battlefield, shooting skills do not exist and exert their effectiveness independently. Before using shooting skills, how to choose the right shooting position, how to properly use tactics occupying positions, how to overcome physical and mental effects in the battlefield environment will all have an important impact on the development of shooting skills. In order to make the trainees generate the shooting abilities required for combat, it is necessary to carry out a comprehensive design of the courses with logical connection in the aspects of tactical basis, combat skills, combat physical ability and combat psychology, so that the courses not only retain the professional purpose of the courses, but also maintain the consistency, coherence and 
practical application of the subjects. By paying attention to the formation of skills while highlighting the practical application, promote the combat ability of the trainees through joint organization and implementation of teachers in related courses under the team teaching mode.

\section{EVALUATE THE TEACHING EFFECTS AND COMPLETION OF TEACHING TASKS SCIENTIFICALLY BY VARIOUS APPROACHES}

A scientific and reasonable evaluation system is an effective way to mobilize the enthusiasm of the team, test its construction results, and improve the core competitiveness of the team. It is also an important guarantee for the orderly operation of the team. A scientific and reasonable evaluation system should be designed around the teaching effect of team teaching and the completion of teaching tasks. In terms of evaluation contents, we should not only pay attention to the evaluation of the teaching process, teaching contents and teaching effects of team teaching, but also pay attention to the improvement of students' quality, the cultivation of students' ability, the influence of team leaders, the cohesion of the team and other implicit results. As for the evaluation methods, we must pay attention to the evaluation of authoritative departments and peers, as well as the evaluation of trainees, because trainees have the most say in the quality of teaching reform and talent training. At the same time, the team's self-evaluation must be fully considered as well. In the evaluation, we should not only pay attention to the evaluation of the final results of team building, but also pay attention to the phased supervision and assessment of the construction process. Through regular inspection and evaluation, all aspects of team teaching can be improved and a virtuous circle can be formed, thereby ensuring the smooth progress of the overall goal of team building. In the direction of evaluation, we should not only pay attention to the evaluation of team teaching reform results, but also pay attention to the transformation of research results into teaching results. Teaching ability and scientific research ability are the comprehensive representation of high-level teachers. It can be said that a high-level teaching team with sustainable development capabilities must be supported by high-level scientific research. Otherwise, its vitality will not last long. The evaluation object should be based on the teaching team and supplemented by individuals. The overall performance of the teaching team should be used as the main basis for assessing the individual performance of the team members. In this way, the collaborative awareness of members of the teaching team can be strengthened to ensure that the overall synergy of the team teaching is maximized.

\section{CONCLUSION}

In recent years, through the teaching practice in related teaching classes, the effectiveness of the team teaching mode reform of military basic curriculum courses based on ability generation is gradually showing. The practical ability of the cadets has been greatly improved, mainly reflecting in:

First, it can establish a team teaching mode for military basic curriculum courses that can be used for reference and promotion. The diversity of team teaching itself meets the inherent characteristics of vocational education. Taking the generation of students' combat ability as the goal, centering on the teaching task, the new team teaching mode of large specialty and pan course teaching will give full play to both the individual and the group advantages of team members, and become a teaching mode that can be used for reference and promotion.

Second, it can effectively improve the comprehensive abilities and qualities of the NCO cadets in the vocational and technical education through the new design and integration of military basic curriculum courses, select a variety of personnel to form a teaching team and implement team teaching according to the courses involved in the curriculum. By giving full play to the individual advantages of teachers and the group advantages of teams, we can show the synergistic effect of team teaching and enhance the practical application of vocational education. Through the discussion and questionnaire survey of the cadets, it is generally reflected that in this teaching mode "the training is close to the post requirements, the content is closely related to the combat requirements, the curriculum evaluation is ability oriented. The degree of trainee participation is deeper and the teaching is more targeted." Third, it is able to train a team of teachers adapted to practical tasks. The promotion and application of this teaching mode can make up for the shortcomings of the individual abilities and qualities of the teachers. In accordance with the post requirements, organize the military basic curriculum courses teaching team and break the boundaries of courses, disciplines and various teaching units, so as to achieve their own strengths and be used for teaching. Through synergy and running-in, it is solidified into a normal mechanism, which can effectively form an integrated teaching force, and the overall teaching level of the teaching staff will be greatly improved.

\section{REFERENCES}

[1] Xu Jinyong, \& Gao Qiuyan, An Analysis of the Basic Charateristics of the University Teaching Teams, J. Journal of Ningbo University, 2(2008) 62-64.

[2] Sun Lina, \& He Lijun., The Reform of Teaching Organization and the Construction of Teaching Teams in Colleges and Universities, J. Journal of Hebei, 5(2007)162-165. 
[3] Gao Bo, \& Zhao Rong, \& Huang Chengjun, The Present Situation and Countermeasures of Miliatarty Basic Teaching Team Construction in Academic Institutions, J.Chinese Military Education,6( 2011)4649.

[4] Zhang Jincun, \& Du Ruicheng, Explore a New Mode of "Team Teaching" to Adapt to Vocational Educaton, J.Journal of Communication Command College, 4(2011)50-52.

[5] Yuan Junliang, \& Shen Yunling, \& Yuan Yuan, Research and Countermeasures on the Evalutaiton Mechanism of Teachers in Armed Police Colleges and Univesities, J.Journal of Armed Police Command

College, 11(2008)15-16. 